\title{
Correlation of intraoperative parathyroid hormone levels of primary hyperparathyroidism with single adenoma volume and weight: Can optimal criteria be created to end the surgery?
}

\section{Primer hiperparatiroidizmde intraoperatif paratiroid hormon düzeylerinin tek adenom hacmi ve ağırlığı ile ilişkisi: Cerrahiyi sonlandırmak için optimal kriterler oluşturulabilir mi?}

Ismail Alper Tarim ${ }^{1}$, Can Akgüin ${ }^{2}$, Murat Derebey ${ }^{1}$, Mesut Ozturk ${ }^{3}$, Gökhan Selcuk Ozbalci ${ }^{1}$, Cafer Polat ${ }^{1}$

${ }^{1}$ Department of General Surgery, Ondokuz Mayis University Faculty of Medicine, Samsun, Turkey

${ }^{2}$ Department of General Surgery, Şrnak State Hospital, Şrnak, Turkey

${ }^{3}$ Department of Radiology, Samsun Gazi State Hospital, Samsun, Turkey

Corresponding author: Ismail Alper Tarim, MD, Department of General Surgery, Ondokuz Mayis University Faculty of Medicine, Samsun, Turkey E-mail: ismailalpert@gmail.com

Received/Accepted: April 24, 2021 /September 24, 2021

Conflict of interest: There is not a conflict of interest.

\section{SUMMARY}

Objective: To study the relationship of intraoperative parathormone (PTH) decrease levels with solitary parathyroid adenoma (SPA) weight, diameter, and volume of the adenoma in patients with primary hyperparathyroidism (PHPT).

Method: Prospectively evaluation of consecutive patients undergoing parathyroidectomy (PTx) with the diagnosis of PHPT related to SPA. Perioperative biochemical parameters of patients; volume, weight and diameters of adenoma were recorded. Intraoperative PTH drop percentages were calculated. Adenoma diameter and volume were measured and calculated using preoperativ ultrasound. Adenoma was weighed intraoperatively by the surgeon.

Results: Forty-five consecutive patients underwent PTx for a SPA between October 2018 and October 2019. There were 9 men and 36 women, with a mean age of $51 \pm 14.94$ years. A positive correlation was identified between the volume with the weight and maximum diameter of resected parathyroid glands $(\mathrm{r}=0.613, \mathrm{p}<0.001 ; \mathrm{r}=0.871, \mathrm{p}<0.001$, respectively $)$. There was a positive correlation between volume and preoperative PTH levels, albeit a weak one $(r=0.334, p=0.025)$. No significant relationship was found between adenoma volume and ioPTH drop rate $(\mathrm{r}=0.088, \mathrm{p}=0.565)$.

Conclusions: We have not been able to establish criteria based on correlation between PA volume and weight and the ioPTH drop rate that would allow us to make decisions on ending the parathyroidectomy and reducing persistent PHPT cases.

Keywords: Solitary parathyroid adenoma, intraoperative parathyroid hormone, parathyroid gland volume, parathyroid gland weight.

(D) Ismail Alper Tarim
(D) Can Akgün
(D) Murat Derebey
(D) Mesut Ozturk
(D) Gökhan Selcuk Ozbalci
(D) Cafer Polat

ORCID IDs of the authors: I.A.T. 0000-0002-6203-2644 C.A. 0000-0002-8367-0768 M.D. $0000-0002-0654-846 \mathrm{X}$ M.O. 0000-0003-4059-2656 G.S.O. 0000-0003-0768-8306 C.P. 0000-0001-8810-8128 
ÖZET

Amaç: Primer hiperparatiroidizm (PHPT) hastalarında intraoperatif parathormon (PTH) azalma düzeylerinin soliter paratiroid adenom (SPA) ağıllığı, çapı ve adenom hacmi ile ilişkisini incelemek.

Yöntem: SPA ileilişkili PHPT tanısı ile paratiroidektomi (PTx) geçiren ardışık hastaların prospektif olarak değerlendirilmesi. Hastaların perioperatif biyokimyasal parametreleri; adenomun hacmi, ağırlığı ve çapları kaydedildi. İntraoperatif PTH düşüş yüzdeleri hesaplandı. Adenom çapı ve hacmi preoperatif ultrason kullanılarak ölçüldü ve hesaplandı. Ameliyat sirasinda cerrah tarafindan adenom tartıldı.

Bulgular: Ekim 2018 ile Ekim 2019 arasında 45 ardışık hastaya SPA için PTx uygulandı. Yaş ortalaması $51 \pm 14.94$ olan 9 erkek ve 36 kadın vardı. Rezeke edilen paratiroid bezlerinin ağılığı ile hacim ve maksimum çapı arasında pozitif korelasyon belirlendi (sırasıyla $\mathrm{r}=0.613, \mathrm{p}<0.001 ; \mathrm{r}=0.871, \mathrm{p}<0.001$ ). Hacim ile ameliyat öncesi PTH düzeyleri arasında zayıf da olsa pozitif korelasyon $\operatorname{vard} 1(\mathrm{r}=0,344, \mathrm{p}=0,025)$. Adenom hacmi ile ioPTH düşüş oranı arasında anlamlı bir ilişki bulunamadi $(r=0.088, p=0.565)$.

Sonuç: Paratiroid adenom hacmi ve ağıllı̆ı ile ioPTH düşüş oranı arasındaki korelasyona dayalı, paratiroidektomiyi sonlandırma ve persistan PHPT vakalarını azaltma konusunda karar vermemize izin verecek kriterleri belirleyemedik.

Anahtar sözcükler: Soliter paratiroid adenomu, intraoperatif paratiroid hormonu, paratiroid bezi hacmi, paratiroid bezi ağırlığı.

\section{INTRODUCTION}

Primary hyperparathyroidism (PHPT) is a common disease with curative treatment parathyroidectomy (PTx), which is caused by solitary parathyroid adenoma (SPA) and has a prevalence rate of $80 \%-$ $85 \%{ }^{1,2}$. For SPA-related PHPT cases, whether there is a significant relationship between the weight, diameter, and volume of the adenoma and the biochemical parameters of hyperparathyroidism and the rate of intraoperative parathormone $(\mathrm{PTH})$ decrease remains controversial ${ }^{3-7}$. With the possibility of a correlation between these parameters, the question of whether the criteria for adequate and curative surgery differs in weight and diameter in SPAs becomes relevant. If this correlation is revealed, it may be possible for surgeons to decrease the rate of persistent or recurrent hyperparathyroidism. Due to the lower success rate and higher mortality and morbidity of reoperations for persistent or recurrent primary hyperparathyroidism, detection and excision of all enlarged parathyroid tissue in the first surgery is the main purpose of operative management in PHPT $^{8}$.

In our literature review (PubMed), a prospective study investigating the relationship between the biochemical parameters of hyperparathyroidism and SPA volume measured by ultrasound (USG) and the adenoma weight measured intraoperatively in the preoperative period was not identified. Our aim in this study was to investigate the relationship between SPA volume measured by USG in the preoperative period and intraoperatively measured adenoma weight and ioPTH drop rates as criteria to decide to end the surgery.

\section{MATERIAL AND METHODS}

This study was conducted prospectively with the approval of our institution's ethics committee. Patients who underwent PTx with the diagnosis of PHPT related to SPA in Ondokuz Mayss University Faculty of Medicine General Surgery Department were included in this study. A single general surgeon conducted resected parathyroid adenoma in all these patients (C.P.).

Among the patients who applied to our clinic, patients with hypercalcemia (calcium> $10.6 \mathrm{mg} / \mathrm{dl}$ ) and high plasma intact PTH (> $65 \mathrm{pg} / \mathrm{mL}$ ), 24-h urinary calcium levels $>100 \mathrm{mg} / \mathrm{dL}$, as well as patients who had pathological confirmation of parathyroid adenoma or parathyroid hyperplasia were included in the study. Patients with multiple endocrine neoplasia, multiple gland disease, and parathyroid canceras well as patients who were operated for secondary and tertiary hyperparathyroidism were excluded.

The age and gender of the patients were recorded. Serum calcium, phosphorus, PTH, creatinine, albumin, alkaline phosphatase (ALP), and serum $25 \quad(\mathrm{OH}) \quad \mathrm{D} \quad(\mathrm{ng} / \mathrm{mL})$ levels were studied preoperatively, postoperative $24 \mathrm{~h}$, postoperative 3 months, and postoperative 6 months. In addition, PTH was studied at the tenth minute intraoperatively. Parathormone drop percentage (\% decrease in ioPTH) was calculated according to the differences between preoperative PTH and intraop 10-min PTH.

All patients underwent preoperative localization investigations using a high-resolution neck USG and Tc99m-sestamibi scintigraphy. USG examinations of the patients were performed by a 
radiologist and a surgeon using a Siemens ACUSON S2000 (Siemens Medical Solutions, MountainView, CA, USA) equipped with an 18$\mathrm{MHz}$ transducer. All patients were positioned supinely, with the neck slightly extended. During $\mathrm{B}$-mode examination, the size of the lesion in three diameters and its volume were noted. The volume calculation was based on ellipsoid assumption in which the volume was calculated as length $\mathrm{x}$ breadth $\mathrm{x}$ height $\mathrm{x} 0.523$. The localizations (upper right, lower right, upper left, lower left, and intrathymic) of SPAs detected by preoperative USG were recorded. Intraoperatively, cases in which the SPA detected in localization was incompatible with that determined in USG were excluded from the study.

The indications for PTx include symptomatic PHPT, and asymptomatic PHPT with one or more criteria (patient's serum calcium level, bone mineral density, the risk of a fragility fracture, kidney stone, or a reduction in creatinine clearance), as defined by the National Institute of Health guidelines ${ }^{9}$.

A planned focused PTx was performed on all patients. Four patients had partial thymectomy, and one with papillary thyroid cancer had PTx and total thyroidectomy. The resected parathyroid gland was weighed and recorded in grams intraoperatively by the surgeon. Although a 50\% reduction in postexcision PTH has been described as a criterion for successful exploration, we preferred to also observe a postexcision level that fell within the normal range. Frozen sections were made in all cases. After applying study inclusion criteria, the study population was composed of 45 PHP patients who underwent PTx with a minimum of 6 months postoperative follow-up. Patients with serum PTH, calcium, and phosphorus results within normal limits at the postoperative sixth month were also considered as having sufficient surgery and curative treatment.

Correlation coefficients were calculated for parathyroid adenoma weight and volume with preoperative biochemical markers. The percentage decrease of PTH levels from baseline $10 \mathrm{~min}$ postexcision were also correlated with parathyroida denoma weight and volume.

\section{Statistical Analysis}

All statistical analyses were performed using IBM SPSS V23. Compatibility with normal distribution was checked with the Shapiro Wilk test. The relationship between the volume values without normal distribution and other parameters was evaluated with Spearman rank correlation. The significance level was taken as $\mathrm{p}<0.05$.

\section{RESULTS}

Forty-five consecutive patients with PHPT were included in our research, and they underwent PTx. Nine $(20 \%)$ of the patients were man, $36(80 \%)$ were women, and the mean age was $51 \pm 14.94$. Localization of adenomas was found in the lower right at 14 patients (31\%), lower left at 12 patients (27\%), upper right at 10 patients (22\%), and upper left at 9 patients (20\%). In 1 (2\%) case, papillary thyroid cancer also accompanied parathyroid adenoma. Four (9\%) of the adenomas were located intrathymically (Table 1).

As shown in Table 2, the mean preoperative parathyroid hormone level was $161.52 \pm$ $133.73 \mathrm{pg} / \mathrm{mL}$, mean serum calcium was $10,91 \pm 0,50 \mathrm{mg} / \mathrm{dl}$, and mean serum phosphorus was $2.77 \pm 0.46 \mathrm{mg} / \mathrm{dl}$. The weight of adenomas ranged between 0.19 to $6.04 \mathrm{~g}$, with a mean weight of 1.40 $\pm 1.20 \mathrm{~g}$. Adenoma volume ranged from 0.05 to $8.05 \mathrm{~cm}^{3}$, with a mean volume of $1.08 \pm 1.47 \mathrm{~cm}^{3}$ measured by USG. The mean maximal diameter of adenomas was $18.38 \pm 9.19 \mathrm{~mm}$. The mean percentage decrease of intraoperative postexcision PTH levels was $72.20 \pm 16.02$ at $10 \mathrm{~min}$.

As shown in Table 3, a positive correlation was identified between the volume with the weight and maximum diameter of resected parathyroid glands $(\mathrm{r}=0.613, \mathrm{p}<0.001 ; \mathrm{r}=0.871, \mathrm{p}<0.001$, respectively). There was a positive correlation between volume and preoperative PTH levels, albeit a weak one $(\mathrm{r}=0.334, \mathrm{p}=0.025)$. Furthermore, a negative and weak significant correlation between volume and preoperative serum phosphorus $(\mathrm{r}=-0.309$, $\mathrm{p}=0.039$ ) was identified. No significant relationship was found between adenoma volume and ioPTH drop rate $(r=0.088, p=0.565)$. 
Table 1: Study patient population characteristics $(\mathrm{N}=45)$

\begin{tabular}{|c|c|}
\hline Patient Characteristics & $\begin{array}{c}\text { Number of } \\
\text { Patients (\%) }\end{array}$ \\
\hline Gender & \\
\hline Man & $9(20)$ \\
\hline Women & $36(80)$ \\
\hline $\begin{array}{l}\text { Age (years), mean } \pm \text { s.d. } \\
\text { Location }\end{array}$ & $51 \pm 14.94$ \\
\hline Right inferior parathyroid gland & $14(31)$ \\
\hline Right superior parathyroid gland & $10(22)$ \\
\hline Left inferior parathyroid gland & $12(27)$ \\
\hline Left superior parathyroid gland & $9(20)$ \\
\hline Intrathymic & $4(9)$ \\
\hline Yes & $41(91)$ \\
\hline No &
\end{tabular}

Table 2: Baseline laboratory parameters in the study subjects $(\mathrm{N}=44)$

\begin{tabular}{|l|c|c|}
\hline Parameter & Mean & Median(Range) \\
\hline Preoperative Serum & & \\
\hline PTH $(\mathrm{pg} / \mathrm{mL})$ & $161.52 \pm 133.73$ & $132.60(41.65-904.9)$ \\
\hline Alkaline phosphatase (U/L) & $131.47 \pm 162.91$ & $96.50(51-1070)$ \\
\hline Calcium (mg/dL) & $10.91 \pm 0.50$ & $10.90(9.6-11.8)$ \\
\hline Phosphorus (mg/dL) & $2.77 \pm 0.46$ & $2.82(1.82-3.64)$ \\
\hline Creatinine (mg/dL) & $0.72 \pm 0.17$ & $0.71(0.39-1.07)$ \\
\hline 25-OH-D levels (ng/ml) & $13.55 \pm 8.04$ & $10.85(2.37-32.46)$ \\
\hline IoPTH(pg/mL) & $42.02 \pm 54.31$ & $29.64(13.08-382.60)$ \\
\hline (\%)decrease in ioPTH & $72.20 \pm 16.02$ & $77.00(15.00-92.00)$ \\
\hline Postoperative $1 \mathrm{st}$ day & & \\
\hline Serum PTH(pg/mL) & $24.40 \pm 14.04$ & $22.00(5.27-63.74)$ \\
\hline Serum Calcium (mg/dL) & $8.86 \pm 0.55$ & $8.90(7.90-10.50)$ \\
\hline Postoperative 6 $6^{\text {th } m o n t h}$ & & \\
\hline Serum PTH $(\mathrm{pg} / \mathrm{mL})$ & $68.70 \pm 34.37$ & $62.00(20.00-205.60)$ \\
\hline Serum Calcium $(\mathrm{mg} / \mathrm{dL})$ & $9.52 \pm 0.45$ & $9.53(8.60-10.40)$ \\
\hline Adenoma characteristics & & \\
\hline Weight $(\mathrm{gr})$ & $1.40 \pm 1.20$ & $0.94(0.19-6.04)$ \\
\hline Volume $\left(\mathrm{cm}^{3}\right)$ & $1.08 \pm 1.47$ & $0.44(0.05-8.05)$ \\
\hline Maximal Diameter $(\mathrm{mm})$ & $18.38 \pm 9.19$ & $16.20(6.90-45.50)$ \\
\hline
\end{tabular}

Table 3: Examining the relationship between the volume of adenoma $\left(\mathrm{cm}^{3}\right)$ and parameters

\begin{tabular}{|l|c|c|}
\hline & $\mathrm{r}$ & $\mathrm{p}$ \\
\hline Age & 0.218 & 0.149 \\
\hline Preoperative Serum & & \\
\hline PTH & 0.334 & $\mathbf{0 . 0 2 5}$ \\
\hline Calcium & 0.199 & 0.189 \\
\hline Phosphorus & -0.309 & $\mathbf{0 . 0 3 9}$ \\
\hline Alkaline phosphatase & 0.186 & 0.263 \\
\hline 25-OH-D levels & -0.215 & 0.177 \\
\hline ioPTH & 0.235 & 0.121 \\
\hline \% decrease in ioPTH & 0.088 & 0.565 \\
\hline Weight & 0.613 & $<\mathbf{0 . 0 0 1}$ \\
\hline MaximalDiameter & 0.871 & $<\mathbf{0 . 0 0 1}$ \\
\hline & \multicolumn{2}{|l}{} \\
\hline
\end{tabular}

r: Spearman correlation coefficient 


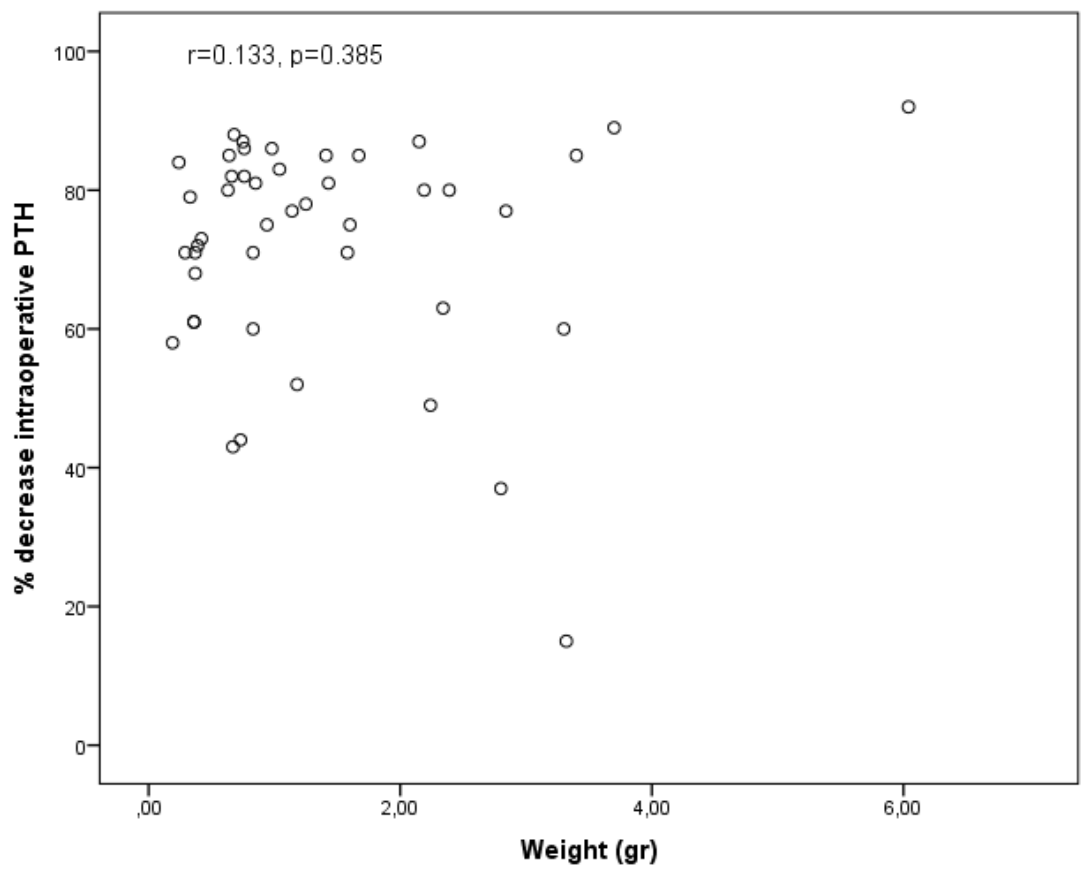

Figure 1: Relationship between parathyroid adenoma weight (gr) and percentage decrease of intraoperative PTH levels at 10-min postexcision.

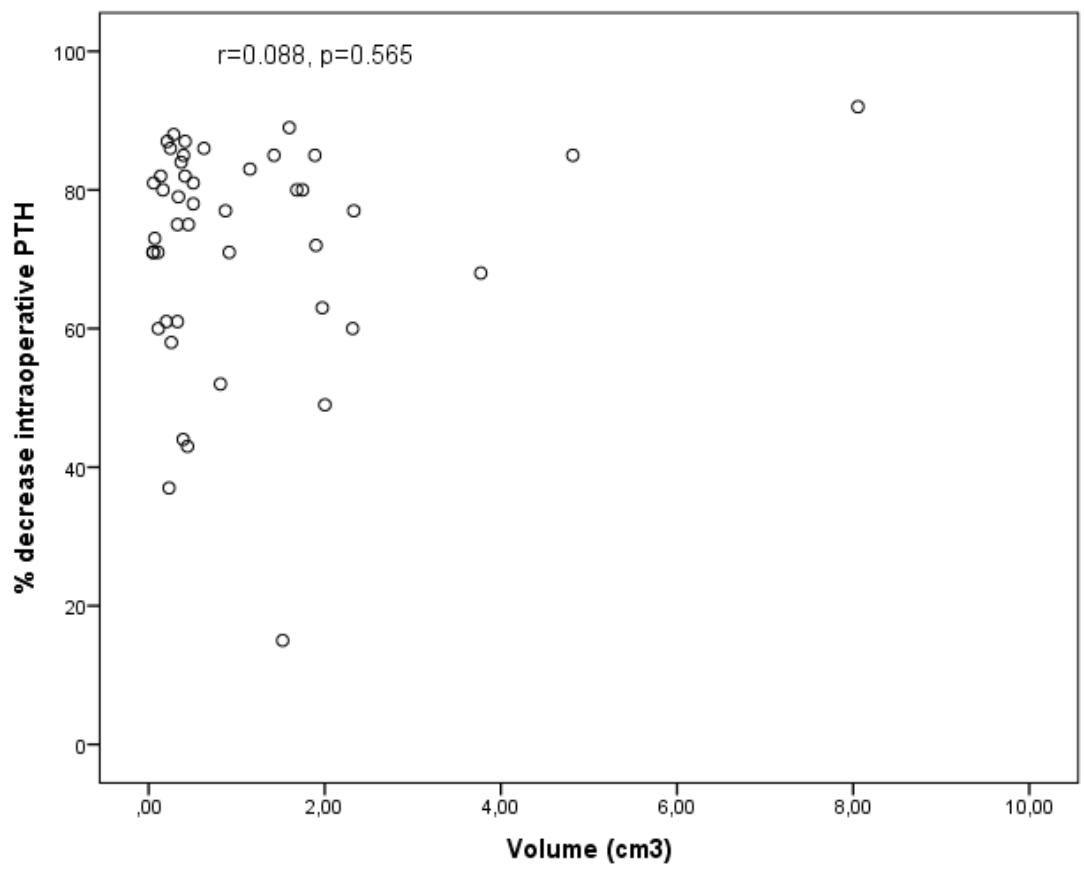

Figure 2: Relationship between parathyroid adenoma volume $\left(\mathrm{cm}^{3}\right)$ and percentage decrease of intraoperative PTH levels at 10-min postexcision 
There was no significant relationship between weight and decrease in ioPTH $(r=0.133, p=0.385$, Figure 1). Similarly, there was no significant relationship between volume and decrease in $\operatorname{ioPTH}(r=0.088, p=0.565$, Figure 2$)$

\section{DISCUSSION}

Many algorithms and criteria have been proposed to determine the success of PTx, including the most accepted Miami criterion ${ }^{10,11}$. However, none of them have managed to minimize persistent HPT rates. The effect of ioPTH reduction rate on appropriate surgery decisions and the many factors affecting this rate have been discussed ${ }^{11-16}$. In our opinion, if the success rates of PTx can be increased by using an algorithm or certain criteria, it would be possible to reduce both reoperations and complications. The relationship between parathyroid adenoma diameter, volume, and weight and peroperative biochemical parameters remains controversial ${ }^{1-7,17}$. These two pieces of information raise the following questions: Is there a relationship between SPA volume and weight and ioPTH drop rate for SPA? If any, in order to terminate the operation in all SPA cases, can an algorithm or certain criteria be created by measuring adenoma volume and/or by considering the weight of intraop adenoma with preop USG instead of 50\% ioPTH drop rate? Can the number of persistent or recurrent HPT be reduced? Can we manage to reduce morbidity by reducing secondary surgeries?

In many studies examining the relationship between adenoma volume and weight and biochemical parameters, such as PTH, calcium, and phosphorus, the information in pathology reports for adenoma volume and weight was used retrospectively and was calculated according to the dimensions in the volume pathology reports ${ }^{1,4,6,7,12}$. In our study, unlike other studies, adenoma volume and dimensions were measured by USG in the preoperative period, and the weight was taken by the surgeon when the specimen was removed intraoperatively. According to our results, there is a correlation between adenoma volume and weight and largest diameter values $(\mathrm{r}=0.613$, $\mathrm{p}<0.001 ; \mathrm{r}=0.871, \mathrm{p}<0.001$, respectively). Whereas there was a weak correlation between volume and preop PTH $(\mathrm{r}=0.334, \mathrm{p}=0.025)$, no correlation was found with serum calcium $(r=0.199, p=0.189)$. A negative correlation was found between volume and phosphorus $(\mathrm{r}=-0.309, \mathrm{p}=0.039)$. Moretz et al., in common with us, reported a correlation between volume and PTH, but no correlation between volume and calcium ${ }^{7}$. Kamani et al., also in common with Moretz et al., reported in a prospective study involving 69 patient, a correlation between volume and PTH and calcium $(\mathrm{r}=0.327, \mathrm{p}=0.006 ; \mathrm{r}=0.333, \mathrm{p}=0.005$, respectively), but the phosphorus value was not correlated with weight and volume $(\mathrm{r}=-0.101, \mathrm{p}=$ $0.410 ; \mathrm{r}=-0.188, \mathrm{p}=0.122$, respectively)[3]. Randhawa et al. reported that there was no relationship between adenoma and biochemical markers in a retrospective study involving 77 consecutive PHPT patients ${ }^{17}$. We believe that there is a correlation between adenoma volume and weight and the biochemical parameters of hyperparathyroidism as reported in many studies in the literature ${ }^{1-7}$.

In our literature review (PubMed), we found only a few articles investigating the relationship between ioPTH drop rate and adenoma volume and weight $7,18,19$. Most of the articles sought answers to questions, such as how many minutes should ioPTH be run after excision, what the PTH drop rate should be, or how to calculate the drop rate based on the preop highest PTH value or PTH viewed before starting surgery ${ }^{11-16}$. Ours was the first prospective study to investigate the relationship between ioPTH drop rate and adenoma volume and weight in PHPT cases.

There are three studies investigating the relationship between ioPTH drop rate and SPA volume and weight. These studies were conducted by Moretzet al., Fang et al. and Ahmadi et al. ${ }^{7,18,19}$. Fang et al. ${ }^{18}$ and Ahmadi et al. ${ }^{19}$ carried out their investigations in patients with secondary hyperparathyroidism. The only study of PHPT cases that is similar to ours, albeit retrospectively, was the study of Moretzet al. ${ }^{7}$. In our study, there was no correlation between ioPTH drop rate and weight and volume $(r=0.133, p=0.385$, Figure 1 ; $r=0.088, p=0.565$, Figure 2, respectively). Fang et al. ${ }^{18}$ claimed that there was a correlation between weight and volume and reduction of PTH, although they implemented their studies using SHPT cases. Ahmadi et al. ${ }^{19}$ reported that there was no relationship between adenoma mass, and PTH. Moretz et al. ${ }^{7}$ indicated that the ioPTH drop rate was correlated with weight but did not find any correlation with volume, as in our study. Our study did not support the results of Moretz et al. and other studies. According to our results, although there was a correlation between adenoma volume and preop PTH, we could not use this as a criterion in terminating the operation, because there was no relationship between PA volume and weight and ioPTH drop rate.

The strengths of our study included the fact that the surgery was performed by a single operator, and 
potentially confounding double adenomas, multi gland hyperplasia, renal hyperparathyroidism, and parathyroid carcinoma cases were excluded. This is the only study in which parathyroid adenoma weight was measured intraoperatively by the surgeon for analysis and in which volume and diameter were measured directly with preoperative USG.

\section{Limitations}

In terms of limitations, the authors agree that conducting this study with 45 patients included the likelihood of potential confounding factors.

Researchers and medical practitioners have not yet been able to create an algorithm or criteria that allows decisionson terminating the operation by considering PA volume and weight and the ioPTH decrease rate in order to reduce persistent PHPT cases. However, studies on the relationship between ioPTH drop rate and adenoma volume and weight should continue with prospective randomized studies performed within a longer timeframe and with more cases.

\section{CONCLUSION}

At this time, we have not been able to establish criteria based on correlation between PA volume and weight and the ioPTH drop rate that would allow us to make decisions on ending the parathyroidectomy and reducing persistent PHPT cases.

Ethics Committee Approval: The study protocol was approved by the Ondokuz Mayıs University Faculty of Medicine Institutional Ethics Committee (approval no: 2018/272, date: 25.06.2018).

\section{REFERENCES}

1. Stern S, Mizrachi A, Strenov Y, Knaanie A, Benbassat C, Shpitzer T, Bachar G (2017) Parathyroid adenoma: a comprehensive biochemical and histological correlative study. Clinical otolaryngology : official journal of ENT-UK ; official journal of Netherlands Society for Oto-Rhino-Laryngology \& Cervico$\begin{array}{llll}\text { Facial Surgery } 42 & \text { (2):381-386. }\end{array}$ doi:10.1111/coa.12761

2. Uludağ M, Aygün N, İşgör A. Main Surgical Principles and Methods in Surgical Treatment of Primary Hyperparathyroidism. Sisli Etfal Hastan Tip Bul. 2019 Dec 3;53(4):337-352. doi: 10.14744/SEMB.2019.67944.

3. Kamani F, Najafi A, Mohammadi SS, Tavassoli S, Shojaei SP (2013) Correlation of biochemical markers of primary hyperparathyroidism with single adenoma weight and volume. The Indian journal of surgery $75 \quad$ (2):102-105. doi:10.1007/s12262-012-0428-5

4. Bindlish V, Freeman JL, Witterick IJ, Asa SL (2002) Correlation of biochemical parameters with single parathyroid adenoma weight and volume. Head \& neck 24 (11):1000-1003. doi:10.1002/hed.10165

5. Williams JG, Wheeler MH, Aston JP, Brown RC, Woodhead JS (1992) The relationship between adenoma weight and intact (1-84) parathyroid hormone level in primary hyperparathyroidism. American journal of surgery 163 (3):301-304. doi:10.1016/00029610(92)90007-e

6. Ramas A, Jakubovic-Cičkisic A, Umihanic S, Sulejmanovic M, Brkic F (2019) Correlation Between the Parathyroid Glands Size and Parathormones Value in Patients with Hyperparathyroidism. Medical archives (Sarajevo, Bosnia and Herzegovina) 73 (4):249252. doi:10.5455/medarh.2019.73.249-252

7. Moretz WH, 3rd, Watts TL, Virgin FW, Jr., Chin E, Gourin CG, Terris DJ (2007) Correlation of intraoperative parathyroid hormone levels with parathyroid gland size. The Laryngoscope $117 \quad$ (11):1957-1960. doi:10.1097/MLG.0b013e31813c14fc

8. Aygün N, Uludağ M. Surgical Treatment of Primary Hyperparathyroidism: Which Therapy to Whom? Sisli Etfal Hastan Tip Bul. 2019 Aug 27;53(3):201-214. doi: 10.14744/SEMB.2019.56873.

9. Bilezikian JP, Brandi ML, Eastell R, Silverberg SJ, Udelsman R, Marcocci C, Potts JT, Jr (2014) Guidelines for the Management of Asymptomatic Primary Hyperparathyroidism: Summary Statement from the Fourth International Workshop. The Journal of Clinical Endocrinology \& Metabolism 99 (10):35613569. doi:10.1210/jc.2014-1413

10. Irvin GL, 3rd, Solorzano CC, Carneiro DM (2004) Quick intraoperative parathyroid hormone assay: surgical adjunct to allow limited parathyroidectomy, improve success rate, and predict outcome. World journal of surgery 28 doi:10.1007/s00268-004-7708-6

11. Richards ML, Thompson GB, Farley DR, Grant CS (2011) An optimal algorithm for intraoperative parathyroid hormone monitoring. Archives of surgery (Chicago, Ill : 1960) 146 (3):280-285. doi:10.1001/archsurg.2011.5 
12. Aksoy SÖ, Adiyaman SC, Çevlik AD, Güray Durak M, Seçil M, Sevinç Aİ. Intra-operative parathyroid hormone evaluation is superior to frozen section analysis in parathyroid surgery. Am J Otolaryngol. 2021 MayJun;42(3):102886.

doi:

10.1016/j.amjoto.2020.102886.

13. Patel KN, Caso R (2016) Intraoperative Parathyroid Hormone Monitoring: Optimal Utilization. Surgical oncology clinics of North America $\quad 25 \quad$ (1):91-101. doi:10.1016/j.soc.2015.08.005

14. Iacobone M, Scerrino G, Palazzo FF (2019) Parathyroid surgery: an evidence-based volume-outcomes analysis : European Society of Endocrine Surgeons (ESES) positional statement. Langenbeck's archives of surgery 404 (8):919-927. doi:10.1007/s00423-01901823-9

15. Riss P, Kaczirek K, Heinz G, Bieglmayer C, Niederle B (2007) A "defined baseline" in PTH monitoring increases surgical success in patients with multiple gland disease. Surgery 142

(3):398-404.

doi:10.1016/j.surg.2007.05.004

16. Mak N, Li J, Vasilyeva E, Hiebert J, Guo M, Lustig D, Holmes D, Wiseman SM (2020) Intraoperative parathyroid hormone measurement during parathyroidectomy for treatment of primary hyperparathyroidism: When should you end the operation? American $\begin{array}{llll}\text { journal of surgery } 219 & \text { (5):785-789. }\end{array}$ doi:10.1016/j.amjsurg.2020.02.049

17. Randhawa PS, Mace AD, Nouraei SA, Stearns MP (2007) Primary hyperparathyroidism: do perioperative biochemical variables correlate with parathyroid adenoma weight or volume? Clinical otolaryngology : official journal of ENT-UK ; official journal of Netherlands Society for Oto-Rhino-Laryngology \& CervicoFacial Surgery $32 \quad$ (3): 179-184. doi:10.1111/j.1365-2273.2007.01447.x

18. Fang L, Tang B, Hou D, Meng M, Xiong M, Yang J (2015) Relationship between parathyroid mass and parathyroid hormone level in hemodialysis patients with secondary hyperparathyroidism. BMC nephrology 16:82. doi:10.1186/s12882-015-0077-6

19. Ahmadi F, Aghajanzadeh P, Yazdi HR, Maziar S, Gatmiri SM (2016) The relationship between total mass and blood supply of parathyroid glands and their secretion of parathyroid hormone in hemodialysis patients with secondary hyperparathyroidism. Saudi journal of kidney diseases and transplantation : an official publication of the Saudi Center for Organ Transplantation, Saudi Arabia 27 (2):263-269. doi:10.4103/1319-2442.178257. 